\section{IJTAR}

International Journal of Transactional Analysis Research
$3(1), 50-52$

https://doi.org/10.29044/v3i1p50

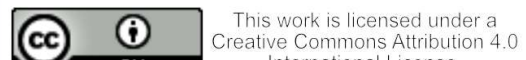
International License.

\title{
Appendix 6: Template of Therapist Session Notes
}

\author{
(C) 2012 Mark Widdowson
}

\section{Case:}

Session:

\section{Date Completed:}

Therapist:

\section{Process Notes}

1. Brief summary of main interventions, episodes and events of session. Please also indicate any key theories (this can include TA or non-TA concepts) which you were using in thinking about the work during the session, or in reflecting upon the session (use other side of page if necessary):

2. Transference/ Countertransference issues and themes:

3. Brief summary of main themes of session:

4. Ideas for next time (from self \& supervision) : 
5. Important Extra-therapy Events (e.g., relationships, work, injury/illness, changes in medication, self-help efforts)

\section{Use of Principles of TA Psychotherapy}

1. What were the client goals that were being addressed by the work in this session?

2. What was the contract for this session and how did it relate to these goals?

3. What methods and interventions were being used to facilitate completion of these goals and the session contract?

4. What methods and interventions were used to facilitate the overall therapy contract and the treatment plan?

5. Briefly describe any particularly powerful part of the session or any parts which felt important and indicate roughly in the session when this occurred.

6. Which schools or approaches of TA did you use most in this session 


\section{Overall Session Ratings:}

1. Please rate how helpful or hindering to your client you think this session was overall. (Check one answer only) THIS SESSION WAS: $\square \quad$ 1. Extremely hindering

$\square \quad$ 2. Greatly hindering

$\square \quad 3$. Moderately hindering

$\square \quad$ 4. Slightly hindering

$\square \quad 5$. Neither helpful nor hindering; neutral

$\square \quad 6$. Slightly helpful

$\square \quad$ 7. Moderately helpful

$\square \quad$ 8. Greatly helpful

$\square \quad$ 9. Extremely helpful

2. How do you feel about the session you have just completed with your client?

$\square \quad$ 1. Perfect

$\square \quad$ 2. Excellent

$\square \quad 3$. Very good

$\square \quad$ 4. Pretty good

$\square \quad$ 5. Fair

$\square \quad 6$. Pretty poor

$\square \quad$ 7. Very poor

3. How much progress do you feel your client made in dealing with his/her problems in this session? $\square \quad$ 1. A great deal of progress

$\square \quad$ 2. Considerable progress

$\square \quad 3$. Moderate progress

$\square \quad$ 4. Some progress

$\square \quad$ 5. A little progress

$\square$ 6. Didn't get anywhere in this session

$\square \quad$ 7. In some ways their problems have got worse this session 